\title{
Model Peningkatan Pemanfaatan Sistem Informasi Rumah Sakit Berdasarkan Metode HOT-Fit di RSPI Prof. Dr. Sulianti Saroso
}

\section{The Model of Improving Hospital Information System Utilization Based on HOT-Fit Method at RSPI Prof. Dr. Sulianti Saroso}

\author{
Anang Suryana ${ }^{1}$, Fransiskus Adikara ${ }^{2}$, MF Arrozi ${ }^{3}$, Akhmad Rizky Taufik ${ }^{4}$
}

1,2,3Program Pasca Sarjana, Universitas Esa Unggul, Jakarta ${ }^{4}$ Rumah Sakit Penyakit Infeksi Prof. Dr. Sulianti Saroso, Jakarta

\section{Penulis Korespondensi}

Anang Suryana

anang.suryana@kemenkopmk.go. id

+6281319482202

\begin{abstract}
Abstrak
Sistem Informasi Manajemen Rumah Sakit (SIMRS) merupakan suatu usaha untuk menyajikan informasi yang akurat, tepat waktu dan sesuai kebutuhan guna menunjang proses fungsi-fungsi manajemen dan pengambilan keputusan dalam memberikan pelayanan kesehatan di rumah sakit. Penelitian ini bertujuan menganalisis pengaruh human, organization, technology, pengetahuan dan regulasi terhadap benefit baik secara simultan maupun parsial. Penelitian ini menggunakan metode penelitian kuantitatif dengan jenis penelitian adalah eksplanatoris kausalitas. Metode analisis yang digunakan yaitu analisis regresi linier berganda. Responden dalam penelitian ini yaitu responden pegawai RSPI Prof. Dr. Sulianti Saroso yang mengoperasikan SIMRS secara langsung sebanyak 154 pegawai. Hasil Penelitian ini diperoleh terdapat pengaruh yang signifikan dari Human, Organization, Technology, Pengetahuan, dan Regulasi berpengaruh terhadap benefit sebesar 80,9\%. Human, Organization, Technology, Pengetahuan, dan Regulasi berpengaruh terhadap benefit secara parsial, dengan ketentuan regulasi merupakan variabel yang paling tinggi mempengaruhi benefit. Regulasi merupakan variabel yang paling dominan mempengaruhi benefit dari penggunaan SIMRS. Berdasarkan hasil penelitian yang telah dilakukan mengenai penerapan SIMRS, dapat diberikan kesimpulan sebagai berikut: Terdapat pengaruh simultan dari faktor human, organisasi, teknologi, pengetahuan, dan regulasi terhadap benefit pada penerapan SIMRS RSPI Prof. Dr. Sulianti Saroso. Hal ini menunjukkan adanya kesinambungan yang baik antara human, organisasi, teknologi, pengetahuan, dan regulasi akan meningkatkan benefit dari penggunaan SIMRS. Pihak rumah sakit tidak hanya memfokuskan pada pengembangan salah satu aspek, namun kelima aspek tersebut dapat lebih dimaksimalkan dan ditingkatkan.
\end{abstract}

\section{Kata Kunci}

HOT-Fit; Evaluasi Sistem Informasi; Tata Kelola Sistem Informasi; SIM Kesehatan

\begin{abstract}
Hospital management requires fast and accurate data management in order to create quality services. Evaluation of an information system is needed to find out the actual condition of system operation so that the achievement of evaluation activities will improve performance in its application. In this essay, Evaluation using the HOT-Fit method which was developed with elements of knowledge and regulation is effective in evaluating the information system. This study aims to analyze the influence of human, organization, technology, knowledge and regulation on benefits, either simultaneously or partially. This study uses quantitative research methods with the type of research is causality explanatory. The analytical method used is multiple linear regression analysis. Respondents in this study were the respondents of RSPI Prof. Dr. Sulianti Saroso who operates SIMRS directly as many as 154 employees. The results of this study indicate that there is a significant influence from Human, Organization, Technology, Knowledge, and Regulations that
\end{abstract}


ARTIKEL

OPEN $\boldsymbol{\sigma}_{\text {ACCESS }}$

affect the benefits of $80.9 \%$. Human, Organization, Technology, Knowledge, and Regulation partially affect the benefits, with the provisions of the regulation being the variable that has the highest influence benefits. Regulation is the most dominant variable affecting the benefits of using SIMRS. It is necessary to improve the quality of SIMRS services related to regulations so that the hospital remains consistent in using quality developers who understand all business processes in hospitals.

\section{Keywords}

HOT-Fit; Information System Evaluation; Information System Governance; Health SIM 


\section{Pendahuluan}

Rumah sakit adalah fasilitas medis yang kompleks, profesional dan padat modal. Kompleksitas ini muncul karena pelayanan rumah sakit mencakup berbagai fungsi pelayanan, pendidikan, dan penelitian, meliputi berbagai disiplin ilmu perilaku dan kedokteran. Agar rumah sakit dapat melakukan tugas kompleks seperti itu, mereka membutuhkan staf khusus di bidang teknologi medis dan perawatan kesehatan. Menurut Peraturan Menteri Kesehatan Republik Indonesia Nomor 46 Tahun 2014 tentang Sistem Informasi Kesehatan, fungsi utama rumah sakit adalah memberikan dan menyelenggarakan pelayanan medis untuk penyembuhan dan pemulihan pasien.

Sistem Informasi Manajemen Rumah Sakit (SIMRS) adalah upaya untuk menyediakan informasi berbasis kebutuhan yang akurat dan tepat waktu untuk mendukung fungsi manajemen dan proses pengambilan keputusan dalam penyediaan layanan medis di rumah sakit. Sistem Informasi Manajemen Rumah Sakit (SIMRS) dirancang untuk berbagai fungsi klinis seperti rekam medis elektronik (EHR), entri pesanan dokter berbantuan komputer (CPOE), dan sistem pendukung keputusan klinis (CDSS) untuk meningkatkan kualitas layanan medis Mendukung dan meningkatkan keselamatan pasien.

Evaluasi sistem informasi juga merupakan upaya praktis untuk menentukan keadaan sebenarnya dari sistem informasi. Berdasarkan evaluasi ini, Anda dapat menentukan keberhasilan implementasi sistem informasi Anda dan merencanakan langkah lebih lanjut untuk meningkatkan kinerja implementasi. Metode HOT Fit dapat digunakan sebagai metode evaluasi sistem informasi.

Metode evaluasi ini menurut teori Yusof dkk. (2006) dalam Sukma dan Budi (2017) mempertimbangkan keseluruhan sistem dengan menyusun empat elemen penting manusia (buman), organisasi (organization), teknologi (technology) dalam sistem informasi dan manfaatnya (Net benefit) juga bisa dilihat dari 4 komponen variabel HOT-Fit serta kesesuaian hubungan di antaranya sebagai faktor-faktor penentu terhadap keberhasilan penerapan suatu sistem informasi.

Menurut teori Yusof dkk. (2006) kerangka kerja baru yang dapat digunakan untuk mengevaluasi sistem informasi, yang disebut kerangka kerja HumanOrganization-Technology (HOT Fit), disediakan.

Model ini menempatkan komponen kunci dari sebuah sistem informasi: manusia (buman), organisasi (organizations), dan teknologi (technology). Dalam penelitian ini peneliti mengimplementasikan model peningkatan penggunaan Sistem Informasi Rumah Sakit (SIMRS) berbasis metode Human, OrganizationTechnology (HOT Fit), yang dikembangkan dengan menambahkan elemen pengetahuan dan aturan di RSPI Prof. Dr. Sulianti Saroso.

Hasil dari model ini, sistem dapat dikembangkan dari tiga faktor utama di atas, dan menurut penelitian Igiany (2019), bahwa model HOT Fit dapat menjawab variabelvariabel apa saja yang berpengaruh terhadap keberhasilan penerapan SIMRS dan menjadikan sebagai kriteria penilaian yang dilakukan di rumah sakit dalam penelitian

Tabel 1. Literatur Utama Hasil Penelusuran

\begin{tabular}{|c|c|c|c|c|c|c|c|}
\hline \multirow[t]{2}{*}{$\begin{array}{l}\text { Sasaran } \\
\text { Program/ } \\
\text { Kegiatan }\end{array}$} & $\begin{array}{l}\text { Indikator } \\
\text { Kinerja }\end{array}$ & Bobot & Target & & & & \\
\hline & & & 2020 & 2021 & 2022 & 2023 & 2024 \\
\hline $\begin{array}{l}\text { Terwujudnyan } \\
\text { Sistem IT yang } \\
\text { lengkap dan } \\
\text { terintegrasi } \\
\text { internal dan } \\
\text { eksternal }\end{array}$ & $\begin{array}{l}\text { Level IT } \\
\text { Terintegrasi }\end{array}$ & $6 \%$ & $\begin{array}{l}\text { Integrated } \\
\text { Enterprise }\end{array}$ & $\begin{array}{l}\text { Integrated } \\
\text { Enterprise }\end{array}$ & $\begin{array}{l}\text { Integrated } \\
\text { Enterprise }\end{array}$ & Advanced & Advanced \\
\hline
\end{tabular}


(Darmawanti \& Idawati, 2019; Igiany, 2019). Studi ini melengkapi pengetahuan dan posisi variabel regulasi yang dapat membantu meningkatkan HOT Fit pada penerapan SIMRS RSPI Prof. Dr. Sulianti Saroso belum diukur terkait keberhasilan penerapannya.

Rumah Sakit Penyakit Infeksi Prof. Dr. Sulianti Saroso adalah rumah sakit khusus Kelas A milik Kementerian Kesehatan, yang berlokasi di Jalan Sunter Permai Raya, Jakarta Utara. Dalam menjalankan pelayanan yang baik RSPI Prof. Dr. Sulianti Saroso didukung oleh sistem informasi rumah sakit yang dituangkan dalam Rencana Strategi Bisnis (RSB) 2020 -2024 dengan sasaran program terwujudnya sistem IT yang lengkap dan terintegrasi internal dan eksternal baik untuk pelayanan, pendidikan, penelitian dan keuangan, kemudian didukung oleh indikator kinerja dengan target level IT terintegrasi secara menyeluruh di rumah sakit. sesuai Tabel 1.

RSPI Prof. Dr. Sulianti Saroso dalam hal ini mengimplementasikan IT Mandiri mulai tahun 2018 dan dilaksanakan secara penuh pada Juli 2018, namun implementasinya baik dari sisi user, sistem, maupun dukungan organisasi. Berdasarkan observasi awal dengan mempertimbangkan fenomena dan permasalahan yang terjadi di RSPI Prof. Dr. Sulianti Saroso menetapkan fenomena keluhan pengguna SIMRS mengenai fungsi operasi sistem seperti aplikasi SIMRS sebagai berikut:

1. Permasalahan terkait manusia (buman), masih terdapat di mana ketersediaan ruang kamar Inap informasinya sebagian masih ada yang tidak real time di mana petugas tidak melakukan update data secara sistem saat pasien keluar, sehingga pengelola ruangan lainnya kesulitan mengetahui kamar mana saja yang tersedia, serta permasalahan lain masih terdapat beberapa pencatatan tindakan perawatan dilakukan secara manual di saat pasien akan keluar rumah sakit pencatatan tersebut dilakukan oleh masing-masing bangsal ruangan untuk mengestimasi sendiri beberapa tindakan perawatan maupun obat-obatan.

2. Permasalahan terkait organisasi dengan ditetapkannya implementasi SIMRS dalam rencana strategi bisnis rumah sakit mengakibatkan budaya dalam organisasi harus menyesuaikan, dalam mendukung implementasi SIMRS tersebut pihak manajemen telah melakukan pelatihan terkait perubahan fitur aplikasi akan tetapi pelatihan tersebut hanya diberikan ke beberapa karyawan (misalnya manajer rumah sakit), permasalahan lainnya setelah dilakukan pelatihan penggunaan SIMRS kepada petugas akan tetapi tidak menerapkan hasil pelatihan tersebut sehingga dampaknya perilaku pengguna masih mengabaikan tata cara pengoperasian SIMRS.

3. Permasalahan pada aspek teknologi adanya ketidaksesuaian modul Aplikasi Gizi yang digunakan ruang IRNA sehingga mengakibatkan sebagian karyawan menolak penggunaan sistem tersebut. Terdapat alat laboratorium baru yang akan dikoneksikan dengan HCLAB Sysmex, namun terkendala dengan Lisensi, Bridging antara Aplikasi Vclaim dan SIMRS yang berdampak penarikan data jadi terlambat. Permasalahan lainnya sebagian server dan komputer pengguna terserang virus yang berdampak pada penggunaan aplikasi bermasalah. Data sebagian belum terintegrasi secara menyeluruh antar unit seperti data billing dengan laporan keuangan yang saat ini masih menggunakan buku laporan manual. Permasalahan lainnya pada modul registrasi sistem tidak dengan baik saat digunakan oleh petugas sehingga data tidak dapat dinput dari fungsi pelayanan sistem seperti data peserta Jaminan Kesehatan Nasional (JKN).

4. Permasalahan pada aspek regulasi, yaitu pengguna yang telah diberikan hak akses ke sistem masih mengalami masalah saat digunakan, dan secara aturan penggunaan SIMRS sebagian belum ada SK penggunaan.

5. Permasalahan pada aspek pengetahuan, kurangnya tenaga ahli di bidang teknologi dan informasi, pengguna SIMRS kesulitan saat terjadi kerusakan karena beberapa pegawai masih belum memahami cara penggunaannya.

Berdasarkan pemaparan di atas, penulis tertarik untuk melakukan penelitian yang berjudul "Model Peningkatan Pemanfaatan Sistem Informasi Rumah Sakit (SIMRS) Berdasarkan Metode Human, Organization Technology-Fit (HOT Fit) di Rumah Sakit Penyakit Infeksi Prof. Dr. Sulianti Saroso", dengan menambahkan unsur pengetahuan dan regulasi.

Komponen aspek manusia (buman) yaitu untuk mengevaluasi sistem informasi dari sisi pengguna sistem, 
sesuai dengan frekuensi dan luasnya fungsi, dan penelitian sistem informasi (Yusof dkk., 2006). Penggunaan sistem juga tergantung pada siapa yang menggunakannya (who use it), tingkat pengguna (level of user), pelatihan, pengetahuan, harapan, dan sikap menerima (acceptance) atau menolak (resistance) sistem. Sistem ini juga mengevaluasi komponen ini dalam hal kepuasan pengguna.

Menurut penelitian yang dilakukan oleh Larinse $\mathrm{dkk}$. (2015) pengguna dapat dihubungkan dengan persepsi manfaat (usefulness) dan sikap pengguna terhadap sistem informasi yang dipengaruhi oleh karakteristik individu.

Sebuah penelitian yang dilakukan oleh Erlirianto dkk. (2015) dengan judul "The Implementation of the Human, Organization, and Technology-Fit (HOT-Fit) Framework to Evaluate the Electronic Medical Record (EMR) System in a Hospital," hasil dari penelitian menemukan bahwa aspek manusia berpengaruh positif terhadap Electronic Medical Record (EMR) selain itu juga merupakan kunci keberhasilan teknologi yang dimiliki oleh sebuah rumah sakit.

Komponen organisasi akan mengevaluasi sistem dinilai dari segi struktur organisasi dan lingkungan organisasi di mana sistem teknologi informasi diimplementasikan secara teoritis (Yusof dkk., 2006). Penelitian yang dilakukan oleh Lynn dkk. (2020) hasil dari penelitian ini menemukan bahwa faktor organisasi secara signifikan memengaruhi cloud organisasi komputasi keputusan adopsi untuk high performance computing (HPC).

Menurut teori yang dikemukakan oleh Yusof dkk. (2006), teknologi adalah seperangkat sarana penyediaan barang yang diperlukan untuk keberadaan dan kenyamanan hidup manusia. Penelitian Nilashi dkk. (2015) menunjukkan bahwa faktor teknologi secara signifikan mempengaruhi keputusan organisasi untuk bigh performance computing (HPC).

Pengetahuan adalah fakta, kebenaran, atau informasi yang diperoleh melalui pengalaman atau pembelajaran teoritis (Venkatesh dkk., 2003). Notoatmodjo (2012), pengetahuan adalah hasil dari mengetahui, yang terjadi setelah seseorang merasakan sesuatu. Persepsi terjadi melalui indra manusia: indra pendengaran, penglihatan, penciuman, perasa, dan peraba.
Sebagian pengetahuan manusia didapat melalui mata dan telinga. Pengetahuan yang tercakup dalam domain kognitif menurut teori dari Notoatmodjo (2012) mempunyai 6 tingkatan, yaitu know, comprehension, application, analysis, synthesis, dan evaluation.

Menurut teori Venkatesh dkk. (2003) regulasi adalah peraturan yang dirancang, dirumuskan, disusun, atau dibuat untuk membantu mengelola kelompok individu, lembaga, organisasi, dan perusahaan dengan tujuan tertentu. Menurut penelitian yang telah dilakukan oleh Triyanti dan Weningsih (2018) regulasi berlaku pada sistem yang akan dibangun, seperti pengelolaan data.

Ada beberapa penelitian terdahulu yang berkaitan dengan penelitian ini yaitu penelitian yang dilakukan oleh Windy dkk. (2020), hasil menunjukkan bahwa data evaluasi yang diperoleh dianalisis secara statistik dengan menunjukkan distribusi frekuensi Persepsi petugas HIS adalah sebagai berikut: responden yang berdasarkan persepsi baik Pada faktor manusia sebanyak 64,9\% responden yang memiliki persepsi baik berdasarkan faktor organisasi adalah $88,3 \%$ dan responden yang memiliki persepsi baik berdasarkan faktor teknologi sebanyak 86,0\%. Manusia, Faktor organisasi, dan teknologi di SIRS RSU Undata Provinsi Sulawesi Tengah adalah sudah bagus tapi masih ada kekurangan untuk pengguna lama, dan aplikasi SIRS tiba-tiba error.

Terdapat pengembangan dalam penelitian ini di mana pada penelitian sebelumnya tidak terdapat variabel pengetahuan dan regulasi sehingga kedua variabel tersebut menjadi pembaruan dalam penelitian ini. Oleh karena itu dapat dirumuskan permasalahan sebagai berikut: apakah variabel aspek buman, aspek organization, aspek technology, aspek pengetahuan, dan aspek regulasi terhadap aspek benefit?

\section{Metode}

Pada penelitian ini menggunakan metode survei kuantitatif untuk jenis survei ini adalah eksplanatoris kausalitas. Pemilihan metode ini memiliki kelebihan yaitu dapat menganalisis dengan tepat secara objektif bahwa variabel berpengaruh atau tidak. Metode pengumpulan data adalah survei, peneliti memilih sejumlah responden sebagai sampel dan mengajukan daftar pertanyaan (kuesioner). Lokasi penelitian ini merupakan lokasi atau objek yang ingin dilakukan suatu 


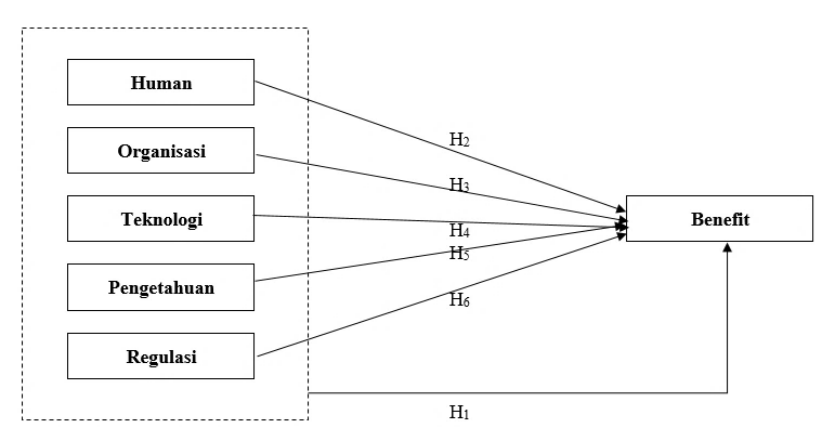

Gambar 1. Kerangka Konseptual Keunggulan Podcast dalam Mendukung Vaksinasi Covid-19 (Hasil Analisis Peneliti)

penelitian. Lokasi penelitian ini diadakan pada Rumah Sakit Penyakit Infeksi Prof. Dr. Sulianti Saroso. Penelitian ini dilakukan dalam jangka waktu tiga bulan dari bulan Juni 2021 hingga bulan Agustus 2021.

Populasi dalam penelitian ini adalah para pegawai RSPI Prof. Dr. Sulianti Saroso yang mengoperasikan SIMRS secara langsung sebanyak 250 pegawai. Besar sampel untuk survei ini adalah 154 responden dengan menggunakan metode Slovin dan teknik sampling Purposive sampling.

Kriteria pengambilan sampel untuk penelitian ini adalah pengguna sistem informasi yang bekerja pada RSPI Prof. Dr. Sulianti Saroso, berpendidikan minimal SMA, dan Pengguna sistem informasi dengan masa kerja lebih dari 1 tahun dan berinteraksi dengan SIMRS di RSPI Prof. Dr. Sulianti Saroso selama 1 tahun.

Data dalam penelitian ini, dikumpulkan melalui kuesioner yang dibagikan kepada responden. Kuesioner penelitian terdiri dari 54 item pertanyaan yang terbagi dalam empat variabel, yaitu Human, Organisasi, Teknologi, Pengetahuan, Regulasi, dan benefit. Kuesioner dibuat dengan mengajukan pernyataan tertutup dan pilihan tanggapan terhadap sampel survei menggunakan skala Likert. interval. Kuesioner berisikan pertanyaan tentang karakteristik responden di antaranya jenis kelamin, umur, pendidikan, masa kerja, dan lama penggunaan SIM.

Sebelum dilakukan penelitian dengan sampel jenuh yang diteliti, peneliti melakukan uji validitas dan reliabilitas menggunakan program SPSS 21 dengan metode Product Moment, untuk menentukan kuesioner tersebut valid dan reliable atau tidak.

Dalam penelitian ini uji validitas menggunakan program SPSS 21 dengan metode Product Moment. Uji validitas menyatakan bahwa variabel tersebut valid dan dapat dianalisis lebih lanjut jika memenuhi kriteria yaitu jika nilai $r$ hitung lebih besar dari $r$ tabel (>). Dengan menggunakan nilai Alpha sebesar 5\%, dari seluruh responden yang berjumlah 50 orang, diperoleh nilai $r$ tabel sebesar 0,279.

Pada variabel human diperoleh ke-6 item memiliki $r$ hitung $>0,279$ sehingga seluruh item valid. Pada variabel organisasi diperoleh ke- 6 item memiliki $r$ hitung $>0,279$ sehingga seluruh item valid. Pada variabel teknologi diperoleh ke-16 item memiliki $r$ hitung $>0,279$ sehingga seluruh item valid. Pada variabel pengetahuan diperoleh ke-7 item memiliki r hitung $>0,279$ sehingga seluruh item valid. Pada variabel regulasi diperoleh ke-11 item memiliki $r$ hitung $>0,279$ sehingga seluruh item valid. Pada variabel benefit diperoleh ke-8 item memiliki $\mathrm{r}$ hitung $>0,279$ sehingga seluruh item valid.

Pengukuran instrumen selanjutnya yaitu uji reliabilitas yang digunakan untuk mengukur seberapa jauh alat ukur digunakan bisa dipercaya. Alat ukur yang digunakan akan Jika jawaban seseorang atas suatu pertanyaan konsisten atau stabil, itu dianggap dapat

Tabel 2. Literatur Utama Hasil Penelusuran

\begin{tabular}{|c|c|c|c|c|}
\hline Variabel & r Tabel & Batas $r$ & Cronbach's Alpha & Keterangan \\
\hline Faktor Human & 0,361 & 0,60 & 0.868 & Valid \& Reliabel \\
\hline Faktor Organisasi & 0,361 & 0,60 & 0.863 & Valid \& Reliabel \\
\hline Faktor Teknologi & 0,361 & 0,60 & 0.934 & Valid \& Reliabel \\
\hline Faktor Pengetahuan & 0,361 & 0,60 & 0.875 & Valid \& Reliabel \\
\hline Faktor Regulasi & 0,361 & 0,60 & 0.906 & Valid \& Reliabel \\
\hline benefit & 0,361 & 0,60 & 0.923 & Valid \& Reliabel \\
\hline
\end{tabular}


diandalkan atau reliabel. jika dilakukan secara berulangulang. Variabel memiliki instrumen yang reliabel jika nilai cronbach's alpha di atas 0,60 . Nilai cronbach's alpha hasil perhitungan yaitu buman $=0,868$; organisasi $=$ 0,863 ; teknologi $=0,934$; pengetahuan $=0,875$; dan regulasi $=0,906$; dan benefit $=0,923$. Hasil uji reliabilitas diketahui bahwa nilai cronbach's alpha lebih besar dari 0,60 untuk masing-masing variabel. Oleh karena itu, alat untuk setiap variabel dapat diartikan reliabel. Artinya alat yang digunakan konsisten sebagai alat ukur.

Kemudian setelah pertanyaan dinyatakan valid dan reliabel peneliti melakukan sampling menggunakan teknik analisis data deskriptif menggunakan Three Box Method yang membagi item skor pertanyaan menjadi rendah, sedang dan tinggi dan teknik pengujian hipotesis melalui Regresi Berganda.

Penelitian ini telah lolos uji etik oleh Dewan Penegakan Kode Etik Universitas Esa Unggul Komisi Etik Penelitian, dengan nomor kaji etik: 0219-21.219/ DPKE-KEP/FINAL-EA/UEU/VIII/2021 Tanggal 6 Agustus 2021 dan ijin penelitian dari Direktur Utama RS dengan Nomor: LB.02.06/XXXVIII/5132/2021 Tanggal 9 Agustus 2021.

\section{Hasil dan Pembahasan}

\subsection{Hasil}

Jumlah responden berdasarkan jenis kelamin diperoleh paling banyak adalah perempuan yaitu sebanyak 97 pegawai atau $63 \%$ sedangkan responden laki-laki yaitu sebanyak 57 pegawai atau 37\%. Hal ini menunjukkan bahwa pegawai perempuan merupakan pegawai yang paling banyak dalam menggunakan dan mengoperasikan SIMRS di RSPI Prof. Dr. Sulianti Saroso.

Jumlah responden berdasarkan pendidikan diperoleh paling banyak adalah tingkat strata 1 atau sarjana yaitu sebanyak 80 pegawai atau $51,9 \%$ selanjutnya pada tingkat SMA yaitu 8 pegawai atau 5,2\%, tingkat Diploma yaitu 32 pegawai atau 20,8\%, dan tingkat Pasca Sarjana (S2/S3) yaitu 34 pegawai atau $22,1 \%$. Hal ini menunjukkan bahwa pegawai yang menggunakan dan mengoperasikan SIMRS di RSPI Prof. Dr. Sulianti Saroso adalah pegawai dengan tingkat pendidikan yang tinggi.

Jumlah responden berdasarkan umur diperoleh paling banyak adalah usia 36-40 tahun yaitu sebanyak 34 pegawai atau 22,1\% dan pada usia 41-45 tahun juga menunjukkan jumlah yang tinggi yaitu 32 pegawai atau $20,8 \%$. Jumlah responden berdasarkan umur, diperoleh usia 20-25 tahun dan 51 tahun ke atas menunjukkan frekuensi paling sedikit. Hal ini menunjukkan bahwa pegawai yang menggunakan dan mengoperasikan SIMRS di RSPI Prof. Dr. Sulianti Saroso adalah pegawai dengan usia produktif.

Jumlah responden berdasarkan masa kerja diperoleh paling banyak adalah di atas 10 tahun yaitu sebanyak 93 pegawai atau $60,4 \%$ sedangkan responden dengan masa kerja di bawah 5 tahun yaitu sebanyak 26 pegawai atau $16,9 \%$, dan responden dengan masa kerja 5-10 tahun yaitu sebanyak 35 pegawai atau 22,7\%. Hal ini menunjukkan bahwa pegawai yang menggunakan dan mengoperasikan SIMRS di RSPI Prof. Dr. Sulianti Saroso paling banyak adalah pegawai yang sudah lama bekerja di RSPI Prof. Dr. Sulianti Saroso.

Jumlah responden berdasarkan lama penggunaan diperoleh paling banyak adalah di atas 5 tahun yaitu sebanyak 108 pegawai atau 70,1\% sedangkan responden dengan lama penggunaan SIMRS di bawah 1 tahun yaitu sebanyak 11 pegawai atau 7,1\%, lama penggunaan 1-3 tahun yaitu 21 responden atau 13,6\%, dan responden dengan lama penggunaan 4-5 tahun yaitu sebanyak 14 pegawai atau $9,1 \%$. Hal ini menunjukkan bahwa pegawai yang menggunakan dan mengoperasikan SIMRS di RSPI Prof. Dr. Sulianti Saroso paling banyak adalah pegawai yang sudah lama menggunakan SIMRS.

Peneliti menganalisis dengan analisis deskriptif yang mana teknik analisis ini didapatkan gambaran tentang tanggapan responden terhadap variabel yang digunakan dalam penelitian. Analisis ini dilakukan dengan menggunakan teknik analisis indeks. Berdasarkan rata-

Tabel 3. Literatur Utama Hasil Penelusuran

\begin{tabular}{|c|c|c|c|c|c|}
\hline \multirow{2}{*}{ No } & \multirow{2}{*}{ Variabel } & \multicolumn{3}{|c|}{ Skor } & \multirow{2}{*}{ Hasi } \\
\hline & & Rendah & Sedang & Tinggi & \\
\hline 1 & Human & & & $\sqrt{ }$ & 123.4 \\
\hline 2 & Organisasi & & & $\sqrt{ }$ & 121.9 \\
\hline 3 & Teknologi & & & $\sqrt{ }$ & 118.8 \\
\hline 4 & Pengetahuan & & & $\sqrt{ }$ & 125.3 \\
\hline 5 & Regulasi & & & $\sqrt{ }$ & 124.9 \\
\hline 6 & benefit & & & $\sqrt{ }$ & 126.8 \\
\hline
\end{tabular}


rata indeks skor Three Box Method maka didapatkan skor rata-rata setiap variabel adalah:

Rata-rata skor eksponensial tanggapan terhadap semua variabel penelitian adalah $>113,1$. Berdasarkan kategori indeks penilaian berdasarkan three box method, dalam hal ini, rata-rata akan berada pada tingkat skor tinggi.

Pengujian pengaruh variabel faktor buman, organisasi, teknologi, pengetahuan, dan regulasi terhadap benefit digunakan metode analisis regresi linier berganda. Hasil regresi berganda diperoleh nilai R2 yaitu 0,809 sehingga diperoleh $\mathrm{e}=1-0,809=0,191$. Oleh karena itu, diagram jalur model yang dihasilkan adalah sebagai berikut:

\subsection{Tahap Uji Hipotesis}

\subsubsection{Uji Parsial}

Uji parsial dirancang untuk menguji pengaruh masing-masing variabel bebas terhadap variabel terikat. Variabel independen memiliki pengaruh signifikan Jika signifikansi lebih kecil dari 0,05 dan nilai $\mathrm{t}$ hitung $>\mathrm{t}$ tabel $\mathrm{t}(0,05 ;(154-6)=1,976$. Tabel 4 merupakan rekapitulasi hasil regresi dan penjelasan.

\subsubsection{Uji Simultan}

Tujuan uji simultan adalah untuk menentukan apakah ada pengaruh yang sama dari variabel independen terhadap variabel dependen. Pengecekan ini dapat dilihat pada output dari tabel ANOVA. Terdapat pengaruh yang sama antara variabel independen jika nilai $F$ hitung lebih besar dari $\mathrm{F}$ tabel dan tingkat signifikansi lebih kecil dari 0,05 . Nilai Fhitung sebesar 125,310 dan taraf signifikansi 0,000 sehingga nilai $F$ hitung lebih besar dari $F$ tabel $(F(0,05 ; 5 ;(1546)=2,275)$ dan taraf signifikansi lebih kecil dari 0,05 maka dapat disimpulkan bahwa terdapat pengaruh simultan antara faktor manusia, faktor organisasi, faktor teknologi, faktor pengetahuan dan faktor regulasi terhadap benefit.

\subsubsection{Koefisien Determinasi}

Koefisien determinasi adalah untuk mengetahui besarnya pengaruh variabel bebas terhadap variabel terikat. Nilai koefisien determinasi akan berkisar antara 0 sampai 1 , semakin mendekati 1 semakin signifikan pengaruhnya. Hasil koefisien determinasi di atas adalah 0,809 maka dapat dikatakan bahwa variabel faktor manusia, organisasi, teknologi, pengetahuan dan peraturan dapat mempengaruhi laba sebesar 80,9\% sedangkan sisanya bertanggung jawab terhadap laba. bukan subjek. dari studi ini.

Berdasarkan hasil analisis dengan regresi berganda, dapat diberikan kesimpulan yaitu : Faktor human, organisasi, teknologi, pengetahuan, dan regulasi terhadap benefit, sehingga dapat diberikan kesimpulan bahwa H1 diterima. Terdapat pengaruh secara parsial yang signifikan dari variabel faktor human terhadap benefit, sehingga dapat diberikan kesimpulan bahwa $\mathrm{H} 2$ diterima. Terdapat pengaruh secara parsial yang signifikan dari variabel faktor organisasi terhadap benefit, sehingga dapat diberikan kesimpulan bahwa H3 diterima. Terhadap benefit, sehingga dapat diberikan kesimpulan bahwa $\mathrm{H} 4$ diterima. Terhadap benefit,

Tabel 4. Literatur Utama Hasil Penelusuran

\begin{tabular}{|c|c|c|c|c|c|}
\hline Variabel & $\begin{array}{l}\text { Unstandardized } \\
\text { Coefficients }\end{array}$ & $\begin{array}{l}\text { Standardized } \\
\text { Coefficients }\end{array}$ & T Stat & Sig. & Keterangan \\
\hline (Constant) & 0,233 & & 2.342 & 0.021 & \\
\hline Human & 0,192 & 0.194 & 2.146 & 0.033 & $\mathrm{H} 2=$ Diterima \\
\hline Organisasi & 0,155 & 0.182 & 2.031 & 0.044 & $\mathrm{H} 3=$ Diterima \\
\hline Teknologi & 0,182 & 0.203 & 3.213 & 0.002 & $\mathrm{H} 4=$ Diterima \\
\hline Pengetahuan & 0,203 & 0.190 & 3.534 & 0.001 & $\mathrm{H} 5=$ Diterima \\
\hline Regulasi & 0,241 & 0.229 & 2.342 & 0.021 & $\mathrm{H} 6=$ Diterima \\
\hline \multicolumn{5}{|c|}{ Fstat; Sig $=125,310 ; 0,000$} & $\mathrm{H} 1=$ Diterima \\
\hline$R 2=0,809$ & & & & & \\
\hline
\end{tabular}

Dependen Variabel = benefit 
Tabel 5. Literatur Utama Hasil Penelusuran

\begin{tabular}{|c|c|c|c|}
\hline No & Variabel & Penjelasan Analisa Hasil Regresi & Kesimpulan \\
\hline 1 & Fakor human & $\begin{array}{l}\text { Variabel faktor human memiliki nilai t-hitung sebesar 2,342 dan nilai signifikansi sebesar 0,021, } \\
\text { maka nilai signifikansi tersebut lebih kecil dari 0,05, sehingga variabel faktor human } \\
\text { berpengaruh signifikan secara parsial terhadap benefit. Nilai koefisien regresi sebesar 0,192 } \\
\text { menunjukkan pengaruh positif, artinya semakin tinggi nilai faktor human maka semakin tinggi } \\
\text { benefit dan sebaliknya. Nilai koefisien ini juga berarti bahwa untuk setiap peningkatan faktor } \\
\text { human, benefit meningkat sebesar 0,192 satuan. }\end{array}$ & $\begin{array}{l}\text { Terdapat pengaruh positif signifikan } \\
\text { dari faktor human terhadap benefit }\end{array}$ \\
\hline 2 & $\begin{array}{l}\text { Faktor } \\
\text { organisasi }\end{array}$ & $\begin{array}{l}\text { Variabel faktor organisasi memiliki t-hitung sebesar } 2,146 \text { dan signifikansi } 0,033 \text {, sehingga } \\
\text { signifikansinya lebih kecil dari } 0,05 \text {, sehingga pengaruh faktor organisasi terhadap benefit } \\
\text { secara parsial signifikan. Jika nilai koefisien regresi } 0,155 \text { berpengaruh positif, semakin tinggi } \\
\text { nilai faktor organisasi maka semakin besar benefit dan sebaliknya. Nilai koefisien ini juga } \\
\text { berarti bahwa benefit meningkat sebesar } 0,155 \text { unit untuk setiap peningkatan unit pada } \\
\text { elemen organisasi. }\end{array}$ & $\begin{array}{l}\text { Terdapat pengaruh positif signifikan } \\
\text { dari faktor organisasi terhadap benefit }\end{array}$ \\
\hline 3 & Faktor teknologi & $\begin{array}{l}\text { variabel faktor teknologi memiliki nilai t-hitung sebesar 2,031 dan nilai signifikansi 0,044, nilai } \\
\text { signifikansinya lebih kecil dari 0,05, maka variabel faktor teknologi berpengaruh signifikan } \\
\text { secara parsial terhadap benefit. Nilai koefisien regresi sebesar 0,182 menunjukkan pengaruh } \\
\text { yang positif, artinya semakin tinggi nilai faktor teknologi maka semakin besar pula benefit yang } \\
\text { diperoleh dan sebaliknya. Nilai koefisien ini juga berarti bahwa benefit meningkat sebesar } \\
0,182 \text { unit untuk setiap peningkatan faktor teknologi. }\end{array}$ & $\begin{array}{l}\text { Terdapat pengaruh positif signifikan } \\
\text { dari faktor teknologi terhadap benefit }\end{array}$ \\
\hline 4 & $\begin{array}{l}\text { Faktor } \\
\text { pengetahuan }\end{array}$ & $\begin{array}{l}\text { Variabel faktor pengetahuan memiliki t-hitung sebesar } 3,213 \text { dan signifikansi } 0,002 \text {, nilai } \\
\text { signifikansinya lebih kecil dari 0,05, sehingga variabel faktor pengetahuan berpengaruh } \\
\text { signifikan secara parsial terhadap benefit. Jika nilai koefisien regresinya } 0,203 \text { berpengaruh } \\
\text { positif, semakin tinggi nilai faktor pengetahuan maka semakin besar benefit, begitu pula } \\
\text { sebaliknya. Nilai koefisien ini juga berarti bahwa untuk setiap peningkatan } 1 \text { unit dalam } \\
\text { koefisien pengetahuan, benefit meningkat sebesar } 0,203 \text { unit. }\end{array}$ & $\begin{array}{l}\text { Terdapat pengaruh positif signifikan } \\
\text { dari faktor pengetahuan terhadap } \\
\text { benefit }\end{array}$ \\
\hline 5 & Faktor regulasi & $\begin{array}{l}\text { Variabel faktor regulasi memiliki t-hitung sebesar } 3,534 \text { dan signifikansi } 0,001 \text {, sehingga } \\
\text { signifikansinya lebih kecil dari } 0,05 \text {, sehingga variabel dominan berpengaruh signifikan secara } \\
\text { parsial terhadap benefit. Nilai koefisien regresi sebesar } 0,241 \text { menunjukkan pengaruh yang } \\
\text { positif, dengan semakin tinggi nilai faktor regulasi semakin meningkatkan benefit dan } \\
\text { sebaliknya. Nilai koefisien ini juga berarti bahwa untuk setiap kenaikan faktor regulasi, benefit } \\
\text { meningkat sebesar } 0,241 \text { satuan. }\end{array}$ & $\begin{array}{l}\text { Terdapat pengaruh positif signifikan } \\
\text { dari faktor regulasi terhadap benefit }\end{array}$ \\
\hline
\end{tabular}

sehingga dapat diberikan kesimpulan bahwa H5 diterima. Terdapat pengaruh secara parsial yang signifikan dari variabel faktor regulasi terhadap benefit, sehingga dapat diberikan kesimpulan bahwa H6 diterima. Tabel 6 merupakan rekapitulasi hipotesis.

\subsection{Pembahasan}

\subsubsection{Human, Organization, Technology, Pengetahuan Pengguna dan Regulasi Berpengaruh Signifikan Secara Simultan terhadap Benefit}

Terdapat pengaruh simultan dari faktor human, organisasi, teknologi, pengetahuan, dan regulasi terhadap benefit. Variabel faktor buman, organisasi, teknologi, pengetahuan, dan regulasi dapat mempengaruhi benefit sebesar 80,9\%. Pada hasil three box diperoleh bahwa kelima variable yaitu buman,

Tabel 6. Literatur Utama Hasil Penelusuran

\begin{tabular}{|c|c|c|c|}
\hline No & Hipotesis & Sig. & Keterangan \\
\hline 1 & $\begin{array}{l}\text { Human, Organisasi, Teknologi, Pengetahuan Pengguna dan Regulasi Berpengaruh Signifikan Secara Simultan Terhadap } \\
\text { Benefit }\end{array}$ & 0.000 & $\mathrm{H} 1=$ Diterima \\
\hline 2 & Human Berpengaruh Signifikan Terhadap Benefit & 0.033 & $\mathrm{H} 2=$ Diterima \\
\hline 3 & Organisasi Berpengaruh Signifikan Terhadap Benefit & 0.044 & $\mathrm{H} 3=$ Diterima \\
\hline 4 & Teknologi Berpengaruh Signifikan Terhadap Benefit & 0.002 & $\mathrm{H} 4=$ Diterima \\
\hline 5 & Pengetahuan Berpengaruh Signifikan Terhadap Benefit & 0.001 & H5= Diterima \\
\hline 6 & Regulasi Berpengaruh Signifikan Terhadap Benefit & 0.021 & H6= Diterima \\
\hline
\end{tabular}


organisasi, teknologi, pengetahuan, dan regulasi memiliki capaian pada kategori tinggi sehinga sejalan dengan capaian variable benefit yaitu pada kategori tinggi. Pada hasil distribusi frekuensi masing-masing jawaban juga diperoleh setiap variable pada setiap item adanya kecenderungan responden menjawab setuju ((pilihan 4). Hal ini mengartikan bahwa adanya benefit yang sangat baik dirasakan oleh pegawai pengguna SIMRS dikarenakan pegawai memiliki faktor human, organisasi, teknologi, pengetahuan, dan regulasi yang baik pula.

HOT Fit adalah salah satu kerangka teoritis yang digunakan untuk mengevaluasi sistem informasi. Model ini awalnya dikembangkan dari penggabungan model sistem informasi Delone \& Mclean yang sukses dengan model organisasi TI yang diusulkan oleh Scott Morton. Model HOT Fit secara komprehensif menggambarkan hubungan timbal balik yang kompleks antara orang, organisasi, dan teknologi. Metode penilaian ini terbukti dalam penelitian berdasarkan kerangka penilaian HOT Fit dari orang, organisasi dan teknologi menurut penelitian Krisbiantoro dkk. (2015).

Menurut penelitian yang dilakukan oleh Erimalata (2016), keberhasilan adopsi teknologi informasi harus diukur secara keseluruhan dengan mengikutsertakan partisipasi organisasi dalam penggunaan teknologi informasi oleh pengguna organisasi. Menurut teori Yusof dkk. (2006) yang bertujuan untuk mengukur keberhasilan sistem informasi yang lebih lengkap dalam memberikan manfaat bagi organisasi, telah mengembangkan model HOT Fit dengan beberapa modifikasi untuk mengevaluasi keberhasilan sistem informasi.

\subsubsection{Human Berpengaruh Signifikan terhadap Benefit}

Variabel faktor manusia berpengaruh positif signifikan terhadap kinerja. Hal ini menunjukkan bahwa semakin tinggi nilai faktor manusia maka semakin tinggi pula keuntungannya dan sebaliknya. Pada hasil three box diperoleh bahwa faktor human memiliki capaian pada kategori tinggi sehingga akan mendorong tingginya benefit dari penggunaan SIMRS. Pengguna yang dapat mengoperasikan SIMRS dengan baik akan mendorong kinerja dan pelayanan rumah sakit. Adanya SMIRS yang saling bersinergi akan memberikan kemudahan dalam akses informasi akan memudahkan interaksi pegawai antar unit dan pekerjaan menjadi lebih fleksibel sehingga hal ini akan meningkatkan kebermanfaatan dari SIMRS dalam mendukung rumah sakit memberikan pelayanan yang terbaik yang tentunya akan berdampak positif pada kepuasan pelanggan.

Hasil penelitian ini sejalan dengan Simorangkir dkk. (2020) yang menyatakan bahwa variabel manusia (buman) mempengaruhi benefit pada studi kasus implementasi SIMRS di RS Dinda Tangerang. Penelitian ini juga sejalan dengan Bayu S. dan Muhimmah (2013) yang menyatakan bahwa faktor buman mempengaruhi keberhasilan penerapan SIMRS pada Rumah Sakit di PKU Muhammadiyah Sruweng.

Menurut teori Yusof dkk. (2006), komponen manusia mengevaluasi sistem informasi dalam hal fungsi dan penggunaannya dalam hal frekuensi dan luasnya penelitian. Penggunaan suatu sistem juga berkaitan dengan siapa yang menggunakannya (who use it), tingkat pengguna (user level), pendidikan, pengetahuan, motif penggunaan, sikap terhadap penerimaan atau penolakan sistem, dan kepuasan pengguna terhadap sistem. Kepuasan pengguna terhadap suatu sistem dapat berhubungan dengan sikap pengguna terhadap suatu sistem informasi, yang dipengaruhi oleh karakteristik pribadi mereka dan prospek keuntungannya. Terdapat penambahan framework dari framework sebelumnya. Artinya, itu termasuk variabel yang dikembangkan sistem. Menurut teori Yusof dkk. (2006), pengembangan sistem terdiri dari perencanaan, manajemen proyek, penjadwalan proyek dan hubungannya dengan strategi TI untuk menciptakan lingkungan sistem dengan tingkat interaksi yang tinggi dan untuk memaksimalkan efisiensi dan akurasi pemantauan proyek.

\subsubsection{Organization Berpengaruh Signifikan terhadap benefit}

Ada pengaruh positif yang penting dari variabel faktor organisasi pada kegunaan. Hal ini menunjukkan bahwa semakin tinggi nilai suatu faktor organisasi maka semakin besar keuntungannya dan sebaliknya. Pada hasil three box diperoleh bahwa faktor organisasi memiliki capaian pada kategori tinggi sehingga akan mendorong tingginya benefit dari penggunaan SIMRS. Dukungan 
pihak manajemen RS serta dukungan teknis yang baik dari RS dalam pemanfaatan SIMRS akan memaksimalkan manfaat dari SIMRS sehingga kegiatan pelayanan di rumah sakit dapat berjalan dengan baik pula. Ada dukungan dari rumah sakit mengenai fasilitas jaringan serta adanya dukungan akan hardware dan software yang baik, akan meningkatkan produktivitas rumah sakit dan secara keseluruhan akan meningkatkan manfaat dari penggunaan SIMRS tersebut.

Hasil penelitian ini sejalan dengan Erlirianto dkk. (2015) yang menyatakan bahwa aspek organisasi yang terdiri dari struktur dan lingkungan, memberikan pengaruh positif dan signifikan terhadap penerapan sistem informasi di rumah sakit. Penelitian ini juga sejalan dengan Lynn dkk. (2020) yang menemukan bahwa faktor organisasi secara signifikan memengaruhi cloud organisasi komputasi keputusan adopsi untuk high performance computing (HPC).

Menurut teori Hutapea dan Thoha (2008) organisasi adalah nilai yang dimiliki dan diakui serta dipahami oleh semua anggota organisasi. Sebuah studi oleh Ardinasari (2017) mendefinisikan budaya organisasi sebagai pola kepercayaan, simbol, ritual, dan mitos yang bertindak sebagai perekat untuk mengintegrasikan suatu organisasi dan terus berkembang dari waktu ke waktu. Budaya perusahaan sering dijelaskan dengan akal sehat. Oleh karena itu, budaya organisasi yang mendukung integrasi teknologi informasi dan pertumbuhan bisnis dapat menjadi faktor kunci dalam mengembangkan implementasi sistem informasi. Oleh karena itu, budaya organisasi dan sistem informasi dapat saling mempengaruhi, dan komponen sistem informasi merupakan bagian dari budaya organisasi.

\subsubsection{Technology Berpengaruh Signifikan terhadap Benefit}

Terdapat pengaruh positif yang signifikan dari variabel faktor teknologi terhadap benefit. Hal ini menunjukkan semakin tinggi nilai faktor teknologi maka benefit akan semakin meningkat begitu pula sebaliknya. Pada hasil three box diperoleh bahwa faktor teknologi memiliki capaian pada kategori tinggi sehingga akan mendorong tingginya benefit dari penggunaan SIMRS. Adanya kecepatan akses yang tinggi dan teknologi yang aktual dalam pelayanan SIMRS akan meningkatkan kemudahan pegawai dalam mengakses informasi dan memberikan pelayanan terbaik. Penyajian data yang update dan juga keamanan data akan meningkatkan penyampaian informasi yang lengkap dan kenyamanan pegawai dalam bekerja dan akses informasi.

Hasil penelitian ini sejalan dengan Ahmadi dkk. (2017) yang menemukan bahwa teknologi berpengaruh signifikan terhadap adopsi sistem informasi rumah sakit (HIS) di rumah sakit umum Malaysia. Hasil penelitian ini juga sejalan dengan Nilashi dkk. (2015) yang menemukan bahwa teknologi merupakan faktor penting dalam adopsi sistem informasi di rumah sakit.

Teknologi informasi merupakan salah satu teknologi yang sedang berkembang dengan pesat pada saat ini. Dengan kemajuan teknologi informasi, pengaksesan terhadap data atau informasi yang tersedia dapat berlangsung dengan cepat, efisien serta akurat. Ada beberapa hal penting yang mendorong diperlukannya teknologi informasi di organisasi, di antaranya: pengambilan keputusan yang tidak dilandasi dengan informasi, informasi yang tersedia tidak relevan, informasi yang ada tidak dimanfaatkan oleh manajemen, informasi yang ada tidak tepat waktu, terlalu banyak informasi, informasi yang tersedia tidak akurat, adanya duplikasi data, dan adanya data yang cara pemanfaatannya tidak fleksibel.

\subsubsection{Pengetahuan Berpengaruh Signifikan terhadap Benefit}

Terdapat pengaruh positif yang signifikan dari variabel faktor pengetahuan terhadap benefit. Hal ini menunjukkan semakin tinggi nilai faktor pengetahuan maka benefit akan semakin meningkat begitu pula sebaliknya. Pada hasil three box diperoleh bahwa faktor pengetahuan secara keseluruhan memiliki capaian pada kategori tinggi sehingga akan mendorong tingginya benefit dari penggunaan SIMRS. Pengetahuan pengguna terkait pemahaman komputer, pemahaman internet, pemahaman sistem organisasi di rumah sakit, dan pemahaman manfaat SIMRS menunjukkan adanya pemahaman yang sangat baik dari pegawai pengguna SIMRS. Pengguna SIMRS yang memiliki pengetahuan yang baik akan memudahkan pengguna dalam menggunakan SIMRS tersebut sehingga akses informasi 
dan penggunaan SIMRS menjadi lebih mudah dan meningkatkan kinerja pegawai.

Sesuai dengan Peraturan Menteri Kesehatan Republik Indonesia Pasal 4 Nomor 82 Tahun 2013 tentang Sistem Informasi Manajemen Rumah Sakit, institusi wajib: Setiap Rumah Sakit menyelenggarakan dan mengembangkan SIMRS, serta menyelenggarakan dan mengembangkan SIMRS sebagaimana dimaksud pada ayat (1), meliputi kecepatan, ketepatan, keterpaduan, peningkatan pelayanan, peningkatan efisiensi, kemudahan pelaporan selama pelaksanaan operasi, kecepatan pengambilan keputusan. ; Akurasi dan kecepatan identifikasi masalah Penerapan manajemen, budaya kerja, transparansi, koordinasi antar departemen, dan pengorganisasian strategi yang mudah untuk memahami dan menerapkan sistem untuk mengurangi biaya administrasi. Menurut sebuah studi yang dilakukan oleh Agustin dan Arimbawa (2019), dapat disimpulkan bahwa kualitas sistem dan kualitas layanan mempengaruhi orang, kualitas sistem dan kualitas layanan mempengaruhi organisasi, dan orang tidak. Ada manfaat, tetapi organisasi memengaruhinya. Di sisi lain, menggunakan SIMRS di bagian pendaftaran mengurangi kesalahan.

\subsubsection{Regulasi Berpengaruh Signifikan terhadap Benefit}

Terdapat pengaruh positif yang signifikan dari variabel faktor regulasi terhadap benefit. Hal ini menunjukkan semakin tinggi nilai faktor regulasi maka benefit akan semakin meningkat begitu pula sebaliknya. Pada hasil three box diperoleh bahwa faktor regulasi memiliki capaian pada kategori tinggi sehingga akan mendorong tingginya benefit dari penggunaan SIMRS. Regulasi terdiri dari adanya unit tersendiri di rumah sakit, adanya staf analis SIMRS, adanya staf programmer, adanya staf maintenance jaringan, adanya kewajiban penyelenggaraan SIMRS, adanya integrasi dengan BPJS Kesehatan adanya SK SIMRS, kerja sama dengan pengembang, keterlibatan rumah sakit dengan pengembangan SIMRS, adanya pelatihan pengguna SIMRS. Keseluruhan indikator pengukuran regulasi menunjukkan capaian yang tinggi sehingga hal ini akan meningkatkan manfaat yang dirasakan dari penggunaan SIMRS. Pegawai menjadi lebih mudah dalam menggunakan SIMRS yang tentunya akan meningkatkan kinerja dan produktivitas sumah sakit.

Regulasi adalah kegiatan publik yang dilakukan oleh masyarakat dan harus memenuhi standar dan aturan sesuai dengan kebijakan pelayanan yang ditetapkan untuk kegiatan pelayanan. Berdasarkan survei oleh Cheng dan Tzeng (2014). Berdasarkan hasil pengolahan data yang diperoleh nilai Sig.t $<$ adalah 0,05, dan dalam beberapa kasus, manfaat bersih SIMRS memiliki dampak yang signifikan terhadap faktor people, organization, technology, user knowledge, dan regulatory. dapat disimpulkan bahwa ada.

\section{Kesimpulan}

Terdapat pengaruh simultan dari faktor buman, organisasi, teknologi, pengetahuan, dan regulasi terhadap benefit pada penerapan SIMRS RSPI Prof. Dr. Sulianti Saroso. Hal ini menunjukkan adanya kesinambungan yang baik antara human, organisasi, teknologi, pengetahuan, dan regulasi akan meningkatkan benefit dari penggunaan SIMRS. Pihak rumah sakit tidak hanya memfokuskan pada pengembangan salah satu aspek, namun kelima aspek tersebut dapat lebih dimaksimalkan dan ditingkatkan.

Terdapat pengaruh dari faktor buman terhadap benefit pada penerapan SIMRS RSPI Prof. Dr. Sulianti Saroso. Hal ini menunjukkan bahwa rumah sakit diharapkan mampu meningkatkan kualitas diri pengguna SIMRS yaitu dengan pelatihan-pelatihan.

Terdapat pengaruh dari faktor organisasi terhadap benefit pada penerapan SIMRS RSPI Prof. Dr. Sulianti Saroso. Hal ini menunjukkan bahwa pihak rumah sakit sebagai organisasi, secara maksimal dapat memberikan pelayanan SIMRS sehingga pegawai lebih mudah dan lebih baik dalam menyelesaikan pekerjaannya.

Terdapat pengaruh dari faktor teknologi terhadap benefit pada penerapan SIMRS RSPI Prof. Dr. Sulianti Saroso. Hal ini menunjukkan bahwa teknologi yang digunakan pada SIMRS dapat lebih berkualitas dan lebih mudah digunakan sehingga pihak rumah sakit diharapkan dapat menggunakan pengembang yang berkualitas sehingga kualitas SIMRS lebih baik lagi.

Terdapat pengaruh dari faktor pengetahuan terhadap benefit pada penerapan SIMRS RSPI Prof. Dr. Sulianti 
Saroso. Hal ini menunjukkan bahwa pengetahuan pengguna SIMRS akan meningkatkan benefit sehingga pihak rumah sakit dapat memberikan pelatihan kepada pengguna baik mengenai penggunaan SIMRS maupun materi lainnya seperti sistem organisasi rumah sakit.

Terdapat pengaruh dari faktor regulasi terhadap benefit pada penerapan SIMRS RSPI Prof. Dr. Sulianti Saroso. Hal ini menunjukkan bahwa regulasi yang baik akan meningkatkan benefit dari penggunaan SIMRS. Oleh karena itu, pihak rumah sakit dapat menyusun kebijakan-kebijakan yang mendukung pengembangan SIMRS sesuai Rencana Strategis Bisnis (RSB) Tahun 2020-2024 terkait Sistem Informasi Manajemen Rumah Sakit (SIMRS) dengan sasaran program/kegiatan terwujudnya sistem IT yang lengkap dan terintegrasi internal dan eksternal dengan indikator kinerja level IT terintegrasi

Berdasarkan hasil penelitian yang telah dilakukan mengenai penerapan SIMRS, dapat diberikan saran sebagai berikut:

1. Bagi pihak RSPI Prof. Dr. Sulianti Saroso:

a. Manajemen rumah sakit perlu melakukan koordinasi, sinkronisasi dan pengendalian implementasi regulasi/ kebijakan kepada seluruh unit kerja terkait :

- Peraturan Menteri Kesehatan No 82 Tentang penggunaan SIMRS di rumah sakit.

- Rencana Strategis Bisnis (RSB) Rumah Sakit Tahun 2020-2024.

- Standar Operasional Prosedur (SOP) terkait pengoperasian aplikasi SIMRS yang di tetapkan manajemen rumah sakit

- SK Penggunaan SIMRS dari Direktur Utama bagi pengguna.

b. Melihat luasnya bidang pekerjaan yang ditangani oleh Instalasi SIMRS dalam mendukung pelayanan sistem informasi lebih baik, pihak rumah sakit perlu melakukan penambahan tenaga SDM koordinator dan staf yang sesuai dengan keahliannya di Instalasi SIMRS, yaitu:

- Operasional Layanan Rumah Sakit

- Hardware dan Infrastruktur

- Software dan Pengembangan Aplikasi

\section{- Pengolahan Data dan Administrasi}

c. Rumah sakit perlu menyelenggarakan pelatihan secara berkala 4 bulan sekali meliputi cara pengoperasian aplikasi SIMRS terhadap pengguna sistem di seluruh unit kerja yang mengoperasikan aplikasi SIMRS sesuai Proses Bisnis Pelayanan Utama (Front Office) dan Proses Bisnis Pelayanan Administratif (Back-Office).

d. Pihak rumah sakit dapat penyampaian petunjuk penggunaan SIMRS secara smart digital yang mudah di akses dengan fitur-fitur yang mudah dipahami oleh seluruh unit pengguna di rumah sakit untuk mendukung kinerja operasional sistem yang lebih baik.

e. Rumah sakit melalui instalasi SIMRS perlu melakukan pemeliharaan secara berkala sesuai jadwal meliputi perangkat keras maupun perangkat lunak di semua unit kerja yang memanfaatkan SIMRS

2. Bagi peneliti selanjutnya dapat lebih mengembangkan penelitian ini dengan menganalisis bagaimana pengaruh variabel lainnya terhadap benefit. Selain itu juga dapat menganalisis bagaimana pengaruh variabel pengetahuan dan regulasi jika menjadi variabel mediasi.

\section{Ucapan Terima Kasih}

Dengan telah selesainya penelitian ini penulis ingin menyampaikan ucapan terima kasih kepada, Direktur Utama RSPI Dr. Sulianti Saroso, dosen pembimbing dan pihak lain yang telah memberikan saran dan masukan bagi penyempurnaan tulisan ini.

\section{Referensi}

Agustin, N., \& Arimbawa, I. G. (2019). The Effect of Credit Risk, Capital Adequacy, Liquidity Risk on Financial Performance and Corporate Value. Journal of World Conference (JWC), 1(1), 68-76. https://doi.org/ 10.29138/prd.v1i1.13

Ahmadi, H., Nilashi, M., Shahmoradi, L., \& Ibrahim, O. (2017). Hospital Information System adoption: Expert perspectives on an adoption framework for Malaysian public hospitals. Computers in Human Behavior, 67, 161-189. https://doi.org/10.1016/j.chb.2016.10.023

Ardinasari, I. F. (2017). Kapasitas Individu, Budaya Organisasi, dan Asimetri Informasi pada Penyusunan Anggaran Partisipatif terhadap Budgetary Slack (Studi Kasus SKPD Sleman) [Universitas Negeri Yogyakarta]. https://eprints.uny.ac.id/47188/

Bayu S., A., \& Muhimmah, I. (2013). Evaluasi Faktor-Faktor Kesuksesan Implementasi Sistem Informasi manajemen Rumah Sakit di PKU Muhammadiyah Sruweng dengan Menggunakan Metode Hot-Fit. Seminar Nasional Informatika Medis (SNIMed). https:// journal.uii.ac.id/snimed/article/view/4250

Cheng, M.-C., \& Tzeng, Z.-C. (2014). Effect of Leverage on Firm Market Value and How Contextual Variables Influence this Relationship. Review of Pacific Basin Financial Markets and Policies, 17(01), 1450004. https://doi.org/10.1142/S0219091514500040 
Darmawanti, \& Idawati. (2019). Analisis Kualitas Sistem Informas Manajemen Rumah Sakit Umum Dr. Fauziah Bireun. Serambi Akademica: Jurnal Pendidikan, Sains, dan Humaniora, 7(4), 551-562. http://ojs.serambimekkah.ac.id/serambi-akademika/article/view/ 1482

Erimalata, S. (2016). Pendekatan Hot-Fit Framework dalam Generalized Structural Component Analysis pada Sistem Informasi Manajemen Barang Milik Daerah: Sebuah Pengujian Efek Resiprokal. Jurnal Akuntansi dan Investasi, 17(2), 141-157. https://doi.org/10.18196/ jai.2016.0051.141-157

Erlirianto, L. M., Ali, A. H. N., \& Herdiyanti, A. (2015). The Implementation of the Human, Organization, and Technology-Fit (HOT-Fit) Framework to Evaluate the Electronic Medical Record (EMR) System in a Hospital. Procedia Computer Science, 72, 580-587. https:// doi.org/10.1016/j.procs.2015.12.166

Hutapea, P., \& Thoha, N. (2008). Kompetensi Plus: Teori, Desain, Kasus, dan Penerapan untuk HR dan Organisasi yang Dinamis. Gramedia Pustaka Utama.

Igiany, P. D. (2019). Systematic Review: Faktor yang Mempengaruh Implementasi Sistem Informasi Manajemen Rumah Sakit (SIMRS). Prosiding Seminar Nasional INAHCO 2019, 1, 146-156. https:// publikasi.polije.ac.id/index.php/inahco/article/view/1780

Krisbiantoro, D., Suyanto, M., \& Luthfi, E. T. (2015). Evaluasi Keberhasilan Implementasi Sistem Informasi dengan Pendekatan HOT Fit Model (Studi Kasus: Perpustakaan STMIK AMIKOM Purwokerto). Konferensi Nasional Sistem \& Informatika 2015, 896-901.

Larinse, D. S., Papilaya, S., \& Fibriani, C. (2015). Evaluasi Sistem Informasi Manajemen Rumah Sakit (SIMRS) Menggunakan Metode HOT-Fit pada Pengguna Akhir di RSUD-Talaud.

Lynn, T., Fox, G., Gourinovitch, A., \& Rosati, P. (2020). Understanding the Determinants and Future Challenges of Cloud Computing Adoption for High Performance Computing. Future Internet, 12(8), 135. https:/ /doi.org/10.3390/fi12080135
Nilashi, M., Ahmadi, H., Ahani, A., Ibrahim, O., \& Almaee, A. (2015). Evaluating the Factors Affecting Adoption of Hospital Information System Using Analytic Hierarchy Process. Journal of Soft Computing and Decision Support Systems, 3(1), 8-35. https://www.jscdss.com/ index.php/files/article/view/67

Notoatmodjo, S. (2012). Metodologi Penelitian Kesehatan. Rineka Cipta.

Simorangkir, A. D., Supriyantoro, \& Arrozi. (2020). The Implementation of Hospital Management Information Systems Using Human, Organization, Technology, and Benefit Models at Dinda Hospital Tangerang. Journal of Multidisciplinary Academic, 4(6). https:// digilib.esaunggul.ac.id/the-implementation-of-hospitalmanagement-information-systems-using-human-organizationtechnology-and-benefi t-models-at-dinda-hospitaltangerang-20636.html

Sukma, C., \& Budi, I. (2017). Penerapan Metode Hot Fit dalam Evaluasi Sistem Informasi Manajemen Rumah Sakit di RSUD Jombang. Jurnal Informasi dan Komputer, 5(1), 34-41. https://doi.org/10.35959/ jik.v5i1.94

Triyanti, E., \& Weningsih, I. R. (2018). Manajemen Informasi Kesehatan III Desain Formulir. Kementerian Kesehatan Republik Indonesia.

Venkatesh, V., Morris, M. G., Davis, G. B., \& Davis, F. D. (2003). User Acceptance of Information Technology: Toward a Unified View. MIS Quarterly, 27(3), 425-478. https://doi.org/10.2307/30036540

Windy, W. T., Sari, F. R., \& Chalidyanto, D. (2020). Evaluation of Hospital Information System Using HOT-FIT Method in Hospital in Indonesia. European Journal of Molecular \& Clinical Medicine, 7(5), 639-643. https://ejmcm.com/article_2917.html

Yusof, M. M., Paul, R. J., \& Stergioulas, L. K. (2006). Towards a Framework for Health Information Systems Evaluation. Proceedings of the 39th Hawaii International Conference on System Sciences. https://doi.org/ 10.1109/HICSS.2006.491 